\title{
Effect of Manna and B-Glucan as Feed Additives on Genotoxicity and Immunity on Broilers
}

\author{
El-Seehy, M.A., ${ }^{1}$ El-Moghazy, G.M. ${ }^{2}$, El-Okazy, A.M. ${ }^{2}$, and Suleyman, M.M ${ }^{2}$
}

\begin{abstract}
The present study aims to experiment the Effects of Mannan and $\beta$ - Glucan as Immuno-stimulants, Prebiotics and Antimycotoxigenic when they are used as a feed additives on Broilers in premix, and then the economical recommendation of the affection of Manna and $\beta$ - Glucan in premix. In order to achieve such a purpose, six different types of premix with different concentration of Mannan and $\beta$ - Glucan, to compare the results two groups of broiler been experiments has been done as negative control and positive control.
\end{abstract}

Four bioassays were employed to achieve the purpose of the work.

1) The molecular cytogenetics parameter.

2) The histological parameters.

3) The blood parameters.

4) The physiological parameters

5) The results shows that group (5) and group (6) were the most results which are meets the negative control results in general, that means that the best ratio for Mannan in the premix in between $17 \%$ and $25 \%$ and the best ratio for $B-G l u c a n$ in the premix is $25 \%$, also the results indicated that Manna and B-Glucan have immuno-stimulants, prebiotics and antimycotoxigenic when use as a feed additives on Broilers in premix.

\section{INTRODUCTION}

The use of negative and positive control group is recommended in all mutagenicity tests. According to Preston et al. (1987), positive controls are included to establish the ability of the analyzers to correctly determine aberrations and to ascertain the expected testto-test and animal-to-animal variations, and to establish the sensitivity of a particular test.

Prebiotics are a category of functional food, defined as non-digestible food ingredients that beneficially affect the host by selectively stimulating the growth and/or activity of one or a limited number of bacteria in the colon, and thus improve host health. Gibson and Roberfroid (1995) typically, prebiotics are carbohydrates (such as oligosaccharides), but the definition does not preclude non-carbohydrates. The most prevalent forms of prebiotics are nutritionally classed as soluble fibre. To some extent, many forms of dietary fibre exhibit some level of prebiotic effect. Traditional dietary sources of prebiotics include soybeans, inulin sources (such as Jerusalem artichoke, jicama, and chicory root), raw oats, unrefined wheat, unrefined barley and yacon. Some of the oligosaccharides that naturally occur in breast milk are believed to play an important role in the development of a healthy immune system in infants, but these are not considered prebiotics, as they do not act through the intestinal microflora. Prebiotic oligosaccharides are increasingly added to foods for their health benefits. Some oligosaccharides that are used in this manner are fructooligosaccharides (FOS), xylooligosaccharides (XOS), polydextrose and galactooligosaccharides (GOS). Some monosaccharides such as tagatose are also used sometimes as prebiotics. In petfood also mannooligosaccharides are being used for prebiotic purposes.

Mannan is a plant polysaccharide that is a polymer of the sugar mannose. Detection of mannan leads to lyses in the mannan-binding lectin pathway.It is generally found in yeast, bacteria and plants. Plant mannans have $\beta$ (1-4) linkages. It is a form of storage polysaccharide. Ivory nut is composed of mannan.

$\boldsymbol{\beta}$-Glucans (beta-glucans) are polysaccharides of $\mathrm{D}$ glucose monomers linked by $\beta$-glycosidic bonds. $\beta$ glucans are a diverse group of molecules that can vary with respect to molecular mass, solubility, viscosity, and three-dimensional configuration. They occur most commonly as cellulose in plants, the bran of cereal grains, the cell wall of baker's yeast, certain fungi, mushrooms and bacteria. Some forms of beta glucans are useful in human nutrition as texturing agents and as soluble fiber supplements, but can be problematic in the process of brewing.

Aflatoxins are naturally occurring mycotoxins that are produced by many species of Aspergillus, a fungus, the most notable ones being Aspergillus flavus and Aspergillus parasiticus. Their name is derived from the early work that discovered Aspergillus Flavustoxins. Aflatoxins are toxic and among the most carcinogenic substances known. After entering the body, aflatoxins may be metabolized by the liver to a reactive epoxide

\footnotetext{
${ }^{1}$ Department of genetics, faculty of agriculture,

Alexandria unniveristy, Alexandria.

${ }^{2}$ regional center for food and feed, agricultural research center.

Received March 3, 2013, Accepted May 23, 2013
} 
intermediate or hydroxylated to become the less harmful aflatoxin M1.

The aim of work was to investigate the effects of Mannan and Glucan on:

1. The Immune System of the Broilers.

2. The possible genotoxic effect effect.

\section{MATERIALS AND METHODS}

\section{A- The Experimental Animal:-}

Broilers are chickens (Gallus gallus domesticus) bred and raised specifically for meat production. Chickens are one of the most common and widespread domestic animals, and although the global population has decreased from more than 24 billion in 2003 to 19 billion in 2011, there are more chickens in the world than any other species of bird.

Broilers have a varied diet. They eat insects, worms, fruit, seeds, acorns, grains, slugs, snails, and many other foods. They have a well-developed gizzard (a part of the stomach that contains tiny stones) that grinds up their food.

\section{B- Experimental procedures:-}

A total number of (80) one day old chicken has been been collected from a farm near to Alexandria, and been adapted for 6 days at to laboratory conditions inside prepared hatches, and were treated by all the broilers vaccines to ensure the avoidance of diseases hazard or death, and then the treatments starts to proceed from the $7^{\text {th }}$ day till the $45^{\text {th }}$ day as a commercial conditions of the broilers breeding, and from through all the treatment proceeding the chicken been feed with a typical standard feed been experimented to be free of Aflatoxin and in the same laboratory environmental conditions.

A total number of (6) types of Mannan and $\beta$ Glucan premixes with different concentrations of those were treated as a treatments and added as a $(1.5 \mathrm{gm} / \mathrm{kg}$ feed $)$ as a commercial ratio with a permanent concentration of Aflatoxin $(1 \mu \mathrm{g} / \mathrm{kg}$ feed $)$ to experiment their Immunostimulant and Antimycotoxigenic effect as a feed additives on broilers, and been added.
At the $7^{\text {th }}$ day the total number of (80) chicken were divided into (8) groups each group contained a total number of (10) chicken and had sorted as a Group(1) Negative control, Group(2) Positive control and 6 groups as a treatments as been shown in the table (1):-

In the $45^{\text {th }}$ day the blood was collected from the veins under the wing and the blood was receives in anticoagulants tubes and normal tubes and then the chicken were slighted and blood was smeared on clean slides, liver and bone marrow tissue were removed and subjected to the bioassay as follows.

\section{C- Chromosomal aberrations analysis:-}

Each animal had received $0.5 \mathrm{ml}(4 \mu \mathrm{g})$ colcemid $/ 100$ gm for cells weight of chicken. After four hours the animals were killed and bone marrow were removed. Preparations of chromosome complement were carried out according to the method that described by Seehy (2002b).

Bone marrows were removed by an isotonic and received in a mortar containing isotonic solution and filtered through two layer of nylon mesh and then centrifuged for $10 \mathrm{~min}$. at $2300 \mathrm{rpm}$, and then transferred to a cup containing $20 \mathrm{ml}$ of hypotonic solution $(0.075 \mathrm{M} \mathrm{KCl})$, gently homogenized, and left for $45 \mathrm{~min}$. at $37 \mathrm{C}^{\circ}$. The homogenate was then centrifuged for $10 \mathrm{~min}$, at $2300 \mathrm{rpm}$. The supernatant was discarded and the pellet was then suspended in methanol and glacial acetic acid (3:1), and centrifuged. (Repeat these 4 times).

Cells in fixative were dropped onto very clean glass slides and air dried. Spread cells were stained with $10 \%$ Giemsa (pH 6.8) for 5 min.

Scanning slides for mitotic spreads was conveniently accomplished with a $25 \mathrm{X}$ magnification objective, and analysis was with a $100 \mathrm{X}$ objective. For control of bias, all prepared slides were coded prior to scoring for chromosomal abnormalities; at least 100 scorable metaphases per treatment was investigated for, Stickiness, Deletion, RCF, and Fragment...etc and recorded.

\section{Table 1. classification of Treatments in Experiment.}

\begin{tabular}{cccc}
\hline Groups & $\begin{array}{c}\text { Mannan \% } \\
\text { In premix }\end{array}$ & $\begin{array}{c}\text { B Glucan \% } \\
\text { In premix }\end{array}$ & $\begin{array}{c}\text { Aflatoxin con. } \\
(\boldsymbol{\mu g} / \mathbf{k g} \text { feed })\end{array}$ \\
\hline $\mathbf{1 ( N . C . )}$ & 0 & 0 & 0 \\
\hline $\mathbf{2 ( P . C . )}$ & 0 & 0 & 1 \\
\hline $\mathbf{3}$ & 3 & 1 & 1 \\
\hline $\mathbf{4}$ & 10 & 0 & 1 \\
\hline $\mathbf{5}$ & 17 & 25 & 1 \\
\hline $\mathbf{6}$ & 25 & 25 & 1 \\
\hline $\mathbf{7}$ & 25 & 30 & 1 \\
\hline $\mathbf{8}$ & 32 & 38 & \\
\hline
\end{tabular}




\section{D- Micronucleus test:-}

The peripheral blood smears were obtained through the under wings veins and neck vein. The slides were air-dried for $12 \mathrm{hrs}$ and then fixed in methanol for 10 min, followed by $5 \%$ Giemsa (w/v) staining. Each chicken had 1000 erythrocytes examined, from both peripheral blood and the kidney. To detect micronuclei in erythrocytes, the slides were analyzed using a 1000X oil-immersion lens. Statistical analysis was performed using Student's $t$ test. This method were carried out through (Grisolia and Starling, 2001).
Bovine polyclonal Immune Globulins G (IgGs) were obtained from Sigma (St. Louis, MO). Blood samples of chicks randomly selected from each pen, was collected for determination of serum IgGs concentrations. The method used LC-MS/MS according to Julien et al., (2002).

\section{RESULTS AND DISCUSSION}

A- Analysis Of Chromosomal Aberrations:-

B- Micronucleus Test:-

E- Immune Globulin Analysis:-

Table 2. The total Chromosomal Aberrations of all treatments in the 8 Groups

\begin{tabular}{cc}
\hline Treatments in groups & Total Aberrant Metaphase \% \\
\hline Group 1 & 14 \\
\hline Group 2 & 44 \\
\hline Group 3 & 40 \\
\hline Group 4 & 32 \\
\hline Group 5 & 19 \\
\hline Group 6 & 22 \\
\hline Group 7 & 29 \\
\hline Group 8 & 25 \\
\hline
\end{tabular}

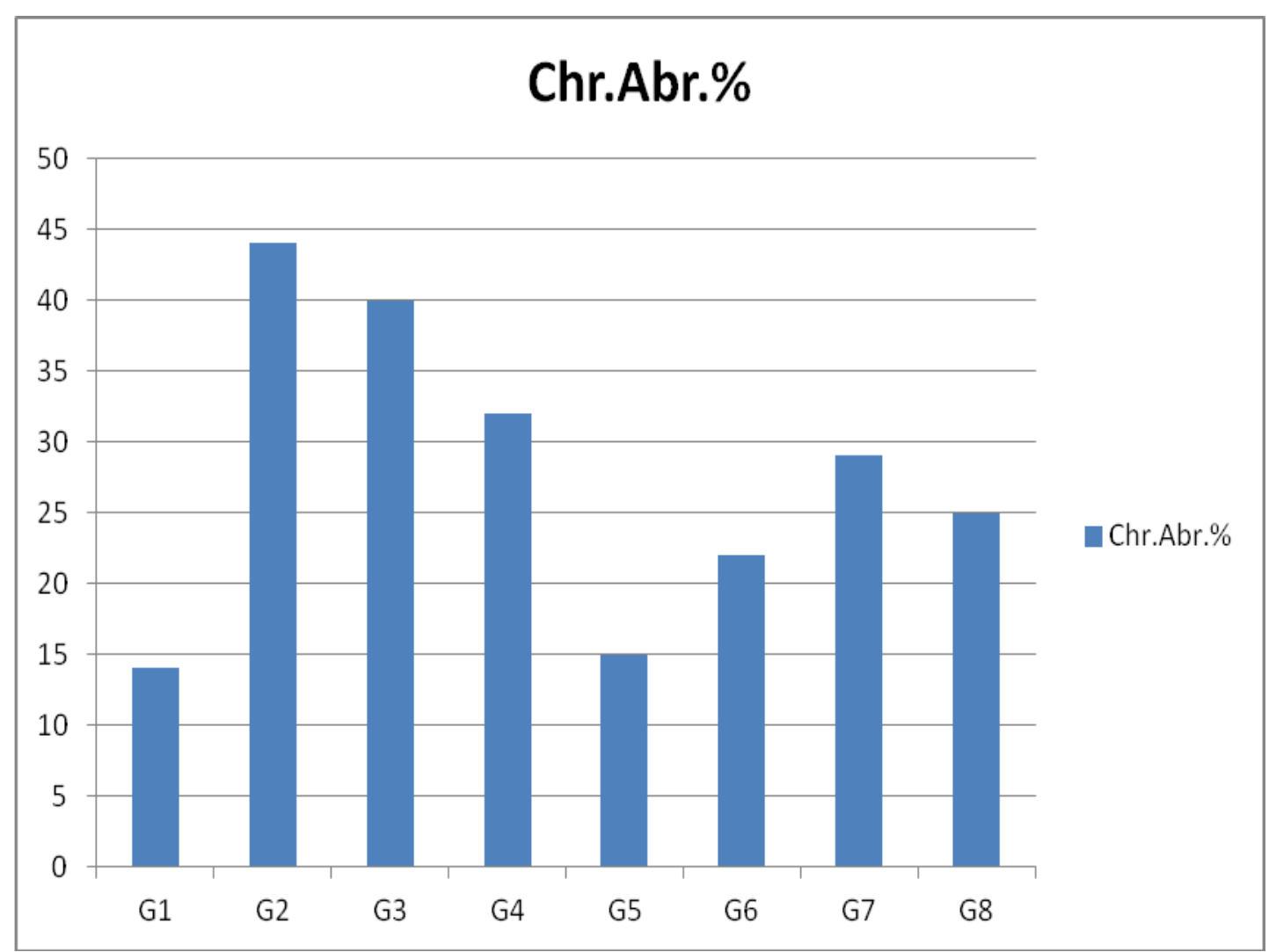

Figure 1. Graph showing the percentage of total Chromosomal Aberration 
Table 2. the results obtained from the analysis of micronucleus obtained from the blood erythrocytes cells of Broilers (Gallus gallus domesticus) after treatment of the 8 Group in precede

\begin{tabular}{cc}
\hline Treatments in groups & Micronucleated Erythrocyte \% \\
\hline Group 1 & $1.47 \pm 0.31$ \\
\hline Group 2 & $11.35 \pm 2.1$ \\
\hline Group 3 & $9.58 \pm 1.8$ \\
\hline Group 4 & $9.54 \pm 1.9$ \\
\hline Group 5 & $2.39 \pm 0.9$ \\
\hline Group 6 & $3.47 \pm 1.3$ \\
\hline Group 7 & $5.41 \pm 1.7$ \\
\hline Group 8 & $6.12 \pm 1.5$ \\
\hline
\end{tabular}

1000cells were counted

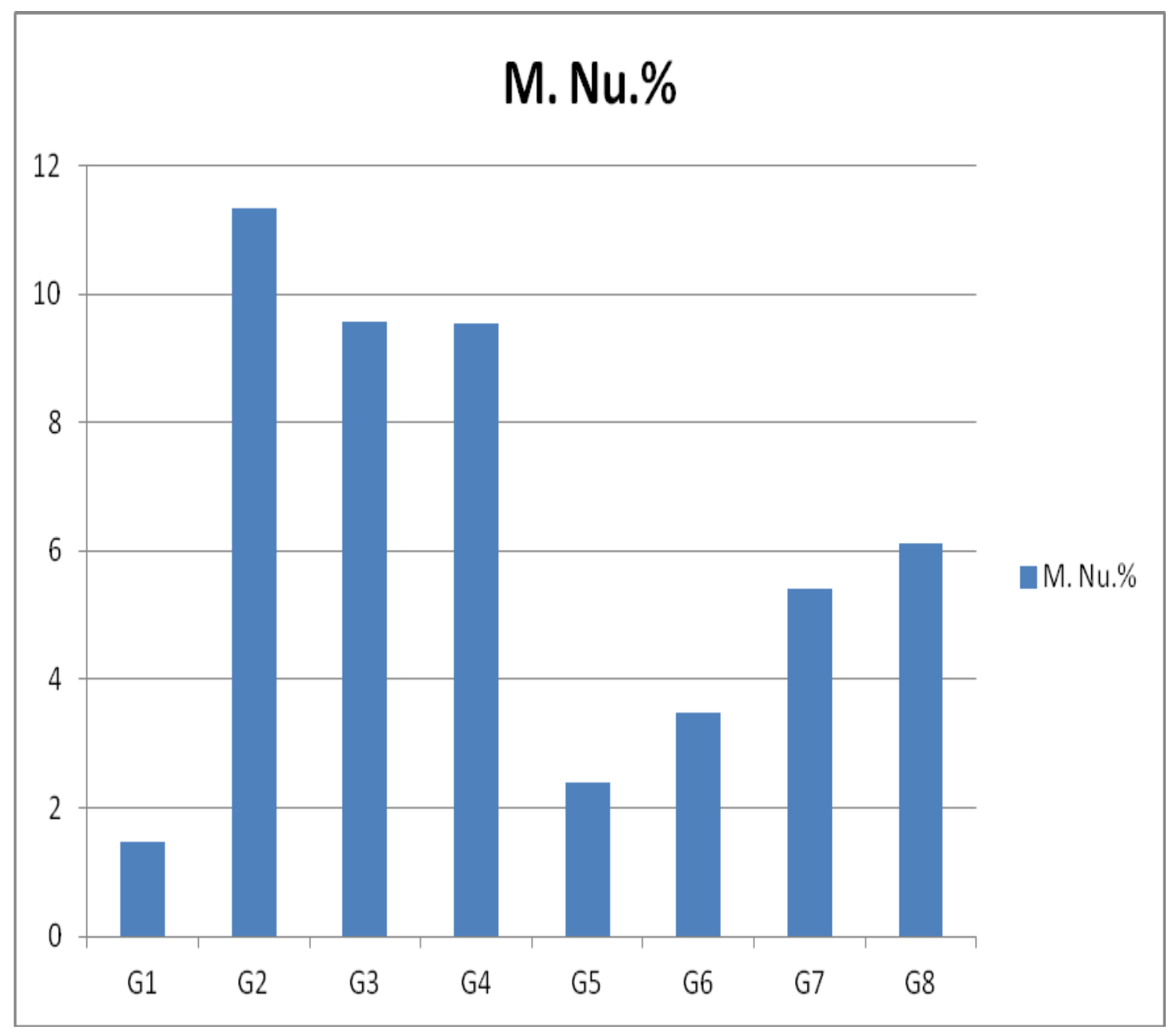

Figure 2. Graph showing the percentage of Micronucleated Erythrocyte

\section{C- Immune Globulin:-}

The effects of the prebiotic on serum IgGs concentrations of broilers are given in Table (4) the difference in IgGs concentrations between the control and experimental groups was not significant, also shows also that Group (6) gives the same results as well as the negative control. 
Table 4. the results obtained from the analysis of Immune Globulins of Broilers (Gallus gallus domesticus) after treatment of the 8 Group in precede

\begin{tabular}{cc}
\hline Treatments in groups & Break Area Measuring \\
\hline Group 1 & $6 \times 10^{7}$ \\
\hline Group 2 & $17 \times 10^{7}$ \\
\hline Group 3 & $13 \times 10^{7}$ \\
\hline Group 4 & $8 \times 10^{7}$ \\
\hline Group 5 & $11 \times 10^{7}$ \\
\hline Group 6 & $6 \times 10^{7}$ \\
\hline Group 7 & $11 \times 10^{7}$ \\
\hline Group 8 & $17 \times 10^{7}$ \\
\hline
\end{tabular}

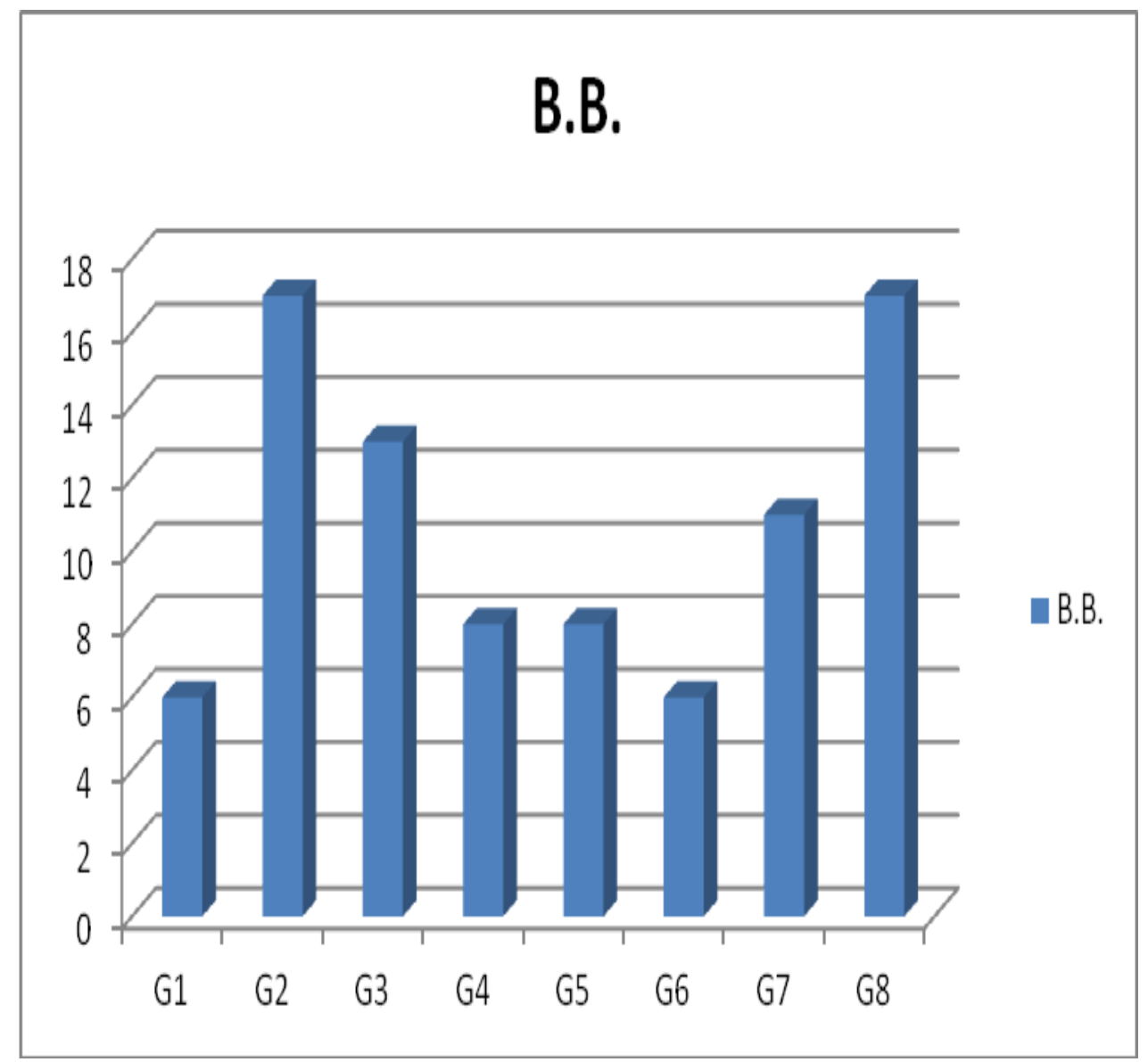

Figure 3. the results obtained from the analysis of Immune Globulins of Broilers (Gallus gallus domesticus) after treatment of the 8 Group in precede

\section{CONCLUSION}

The results obtained from all the parameters shows that Mannan and B-Glucan have an Immuno-stimulants, Prebiotics and Antimycotoxigenic effect when use as a Feed Additives On Broilers, the results shows that he different concentrations of Mannan and B-Glucan in the premix can affect the inhibition of toxins effactions in the feed and can make repair when mixed with feed in case if this case are toxificated, also the results shows that group (5) which is 17\% Mannan and 25\% B-Glucan in premix as a feed additives and group (6) which is $25 \%$ Mannan and 25\% B-Glucan in premix as a feed additives give the most results which are meets the negative control results in general, that means that the best ratio for Mannan in the premix in between $17 \%$ and $25 \%$ and the best ratio for B-Glucan in the premix is $25 \%$. 


\section{REFERENCES}

Gibson GR, Roberfroid MB. Dietary modulation of the human colonic microbiota: introducing the concept of prebiotics. J Nutr. 1995 Jun;125(6):1401-12. PM.

Gonzalo de la Rosa, María Yáñez-Mó, Raphael Samaneigo, Diego Serrano-Gómez, Laura Martínez-Muñoz, Elena Fernández-Ruiz, Natividad Longo, Francisco SánchezMadrid, Ángel L. Corbí and Paloma Sánchez-Mateos, 2005 Regulated recruitment of DC-SIGN to cell-cell contact regions during zymosan-induced human dendritic cell aggregation. Journal of Leukocyte Biology 2005; 77:699-709.
Julian A. Saba, Jeremy P. Kunkel, David C. H. Jan, Werner E. Ens, Kenneth G. Standing, Michael Butler, James C. Jamieson, and He'le'ne Perreault 2002. A Study of Immunoglobulin G Glycosylation in Monoclonal and Polyclonal Species by Electrospray and Matrix-Assisted Laser Desorption/Ionization Mass Spectrometry. Analytical Biochemistry 305, 16-31.

Preston, R.J., Dean, B.J., Galloway, S., Holden, H., McFee, A.F. and Shelby, M. (1987). Mammalian in vivo cytogenetic assays. Analysis of chromosome aberrations in bone marrow cells. Mutat. Res. 189: 157-165.

Seehy, M.A. (2002a). Mutagenicity and carcinogenicity. A critical Review Egypt. J. Genetic Cytol . inpress

Seehy, M. A. (2002b). A rapid preparation of Tilapia chromosomes Egypt, J. genet. Cytol. inpress

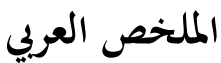

\section{تأثير المنان والبيتاجلوكان كمحفز مناعى وبادىء حيوى ومضاد للسمية الوراثية كاضافات اعلاف}

$$
\begin{aligned}
& \text { للدواجن } \\
& \text { تُمَّمَ الصيحى، جيهان المغازى، احمد العكازى، محمود سليمان } \\
& \text { الهدف من أجراء الدراسة هواختبار دراسة تاثير المنان والبيتا واضحة ان المجموعات(5) و و(6) هم اقرب مان يكون للكنترول } \\
& \text { جلوكان كمحفز مناعى وحيوى ومضاد للسموم الفطرية عند السالب. } \\
& \text { نتائج اختبار النواة الصغيرة اظهر العدد النسبى للنوية الصغيرة فن }
\end{aligned}
$$

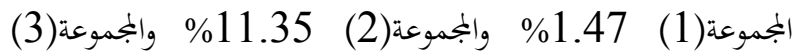

$$
\begin{aligned}
& \text { استخدامه كاضافات علفية للدواجن في صورة مخلوط. ولاجراء هذا } \\
& \text { الاختبار تم تقسيم العدد الكلى ل } 80 \text { فرخ صغير الى } 8 \text { بمموعات تم }
\end{aligned}
$$

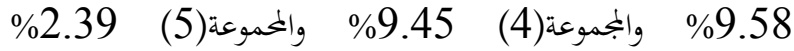

$$
\begin{aligned}
& \text { والمجموعة(6) 3.47\% والمجموعة(7) 5.41\% والمجموعة(8) }
\end{aligned}
$$

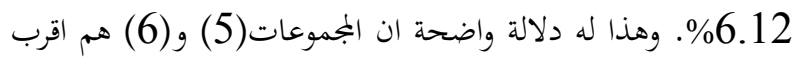

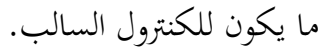

$$
\begin{aligned}
& \text { بتلخيص النتائج الكلية المتحصل عليها نجد ان المموعة(5) } \\
& \text { والمحموعة(6) هم افضل النتائج مقارنة مع الكنترول السالب ونجد } \\
& \text { ايضا من النتائج ان مخاليط الاعلاف المحتوية على المنان والبتاجلوكان }
\end{aligned}
$$

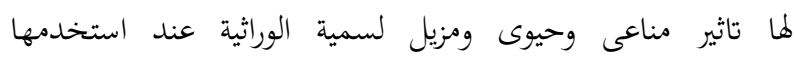

$$
\begin{aligned}
& \text { كاضافات اعلاف للدواجن. }
\end{aligned}
$$

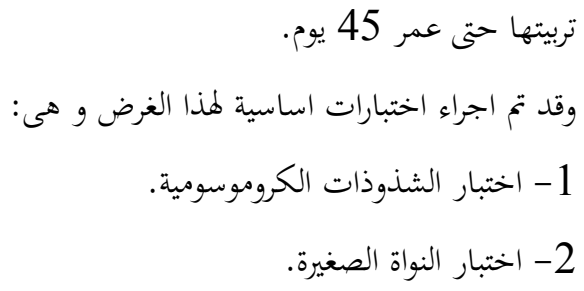

$$
\begin{aligned}
& \text { تحليل الكروموسومات اوضح ان المجموعات تحتوى على العديد } \\
& \text { من الشذوذات التركيبية للكروموسومات وكانت النسبة الكلية } \\
& \text { للشذوذات في المجموعة(1) 14\% والمجموعة(2) 44\% والمجموعة }
\end{aligned}
$$

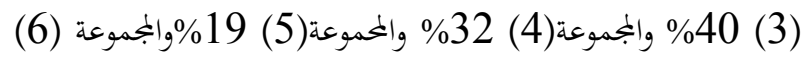

$$
\begin{aligned}
& \text { 22\%والمجموعة(7) 29\% والمجموعة(8) 25\%. وهذا له دلالة }
\end{aligned}
$$

